\title{
Monocyclic Quinone Structure-Activity Patterns: Synthesis of Catalytic Inhibitors of Topoisomerase II with Potent Anti- Proliferative Activity
}

\author{
[a] Prof. Charles M. Marson*,a \\ ${ }^{a}$ Department of Chemistry, \\ University College London, \\ Christopher Ingold Laboratories, \\ 20 Gordon Street, \\ London WCIH OAJ, U.K \\ Orcid ID: 0000-0002-1729-5760 \\ E-mail: c.m.marson@ucl.ac.uk \\ [b] Dr Thomas M. Waugh ${ }^{\text {a }}$ \\ ${ }^{a}$ Department of Chemistry, \\ University College London, \\ Christopher Ingold Laboratories, \\ 20 Gordon Street \\ London WCIH OAJ, U.K. \\ E-mail: thomas.waugh.12@alumni.ucl.ac.uk \\ [c] Prof. John Masters, ${ }^{\text {b }}$ \\ ${ }^{b}$ Prostate Cancer Research Centre, \\ Research Department of Urology, \\ Charles Bell House, \\ University College London \\ 67-75 Riding House Street, \\ London WIW 7EJ, U.K. \\ Email: j.masters@ucl.ac.uk \\ [a] Dr Abil E. Aliev, \\ ${ }^{a}$ Department of Chemistry, \\ University College London, \\ Christopher Ingold Laboratories, \\ 20 Gordon Street \\ London WCIH OAJ, U.K. \\ Email: a.e.aliev@ucl.ac.uk
}

Author(s) ${ }^{[\mathrm{b}]}$ and Corresponding Author(s) ${ }^{*[\mathrm{a}]}$

Supporting information for this article is given via a link at the end of the document.

\begin{abstract}
The monocyclic 1,4-benzoquinone, HU-331, the direct oxidation product of cannabidiol, inhibits the catalytic activity of topoisomerase II but without inducing DNA strand breaks or generating free radicals, and unlike many fused-ring quinones exhibits minimal cardiotoxicity. Thus, monocyclic quinones have potential as anti-cancer agents, and
\end{abstract} investigation of the structural origins of their biological activity is warranted. New syntheses of cannabidiol and ( \pm )-HU-331 are here reported. Integrated synthetic protocols afforded a wide range of polysubstituted resorcinol derivatives; many of the corresponding novel 2-hydroxy-1,4-benzoquinone derivatives are potent inhibitors of the catalytic activity of topoisomerase II, some more so than $\mathrm{HU}-331$, whose monoterpene unit replaced by a 3-cycloalkyl unit conferred increased anti-proliferative properties in cell lines with $\mathrm{IC}_{50}$ values extending below $1 \mathrm{mM}$, and greater stability in solution than HU-331. The principal pharmacophore of quinones related to HU-331 was identified. Selected monocyclic quinones show potential for the development of new anticancer agents.

\section{Introduction}

Quinones, especially derivatives of 1,4-benzoquinone, represent an important group of potent therapeutic agents, ${ }^{[1-}$ 4] especially as antibiotics and anticancer agents, including anthracyclines such as doxorubicin and daunorubicin, ${ }^{[5]}$ as 
well as other streptomyces-derived compounds such as streptonigrin and mitomycin $\mathrm{C}^{[6]}$ and synthetic quinonoids such as mitoxantrone and epirubicin. ${ }^{[7,8]}$ The mechanisms by which anthracyclines and many fused-ring quinones act are complex, multiple pathways usually being involved, including intercalation between base pairs, resulting in the inhibition of RNA and DNA synthesis in cancer cells. ${ }^{[9,10]}$ Secondly, quinones may act as inhibitors of the DNA topoisomerase II enzyme, preventing the relaxation of supercoiled DNA, thereby blocking transcription and replication. ${ }^{[11]}$ Thirdly, they may generate haeme-mediated oxygen radicals that damage DNA, proteins and cell membranes, ${ }^{[12]}$ although not necessarily selectively. Fourthly, anthracyclines have recently been shown to cause histone eviction from open chromatin structures, leading to activation of the DNA damage response or apoptosis of cancer cells. ${ }^{[13]}$

A major therapeutic goal is the advancement of new quinonoid compounds that display anti-neoplastic activity as well as reduced toxicity. However, anthracycline usage is often limited by cardiotoxicity, ${ }^{[4]}$ which also applies to a number of other classes of fused-ring quinones. In particular, chemotherapy using anthracyclines causes cardiomyocte injury, left ventricular dysfunction, and at the upper levels of dosage required for cancer therapy carries a high risk of heart failure and death. ${ }^{[1]}$ Since such cardiotoxicity might arise through undesired intercalation into normal DNA, or through non-selective damage via quinonoid oxy radicals, we considered whether monocyclic quinones (whose lack of ring fusion would be expected to show little DNA intercalation) might confer reduced toxicity compared to their fused-ring congeners, while retaining anti-cancer potency. Indeed, a number of monocyclic 1,4-benzoquinone derivatives (Fig. 1) show promise including ardisianone (inducing antiproliferation and apoptosis of several cancer cell lines, including PC-3, DU-145 and human hormone-refractory prostate cancer), ${ }^{[14]}$ irisoquin, ${ }^{[15]}$ primin, ${ }^{[16]}$ and HU-395, a dihydro derivative of $\mathrm{HU}-331 .{ }^{[17]}$ Embelin, another important monocyclic quinone natural product, is an analgesic which also possesses anti-fertility, anti-inflammatory and antitumour properties. ${ }^{[18]}$

The monocyclic quinone HU-331 is of particular interest, ${ }^{[19-21]}$ since it showed no impairment of heart function, ${ }^{[20]}$ in contrast to doxorubicin cardiotoxicity that was severe in a mouse model, even at only one-third of the concentration of HU-331 administered. Quinone cardiotoxicity is generally thought to arise by generation of reactive oxygen species (ROS), however, in that respect, as well as others, HU-331 shows patterns of biological activity that are atypical of many quinones. The lack of cardiac toxicity upon administration of $\mathrm{HU}-331$ is consistent with findings that observed no production of ROS, ${ }^{[22]}$ as well as other studies which showed that ROS were produced, but were not the cause of cell death. ${ }^{[23]}$ Additionally, in various studies, cell death induced by HU-331 could not be attributed to DNA strand breaks, caspase activation, apoptosis, or cell cycle arrest. ${ }^{[24]}$ Although the main mode of action of HU-331 is thought to be catalytic inhibition of DNA topoisomerase $\| \alpha,{ }^{[20,24]}$ the unusual properties of HU-331 have not been fully accounted for, especially in terms of its molecular structure; despite being of cannabinoid origin, HU-331 does not target cannabinoid receptors. ${ }^{[20]}$ Consequently, of central importance is to gain a detailed understanding of the biological and potentially therapeutic effects as a function of substitution patterns around the quinone ring; as shown in the present study, the extent and nature of substitution can have profound effects.

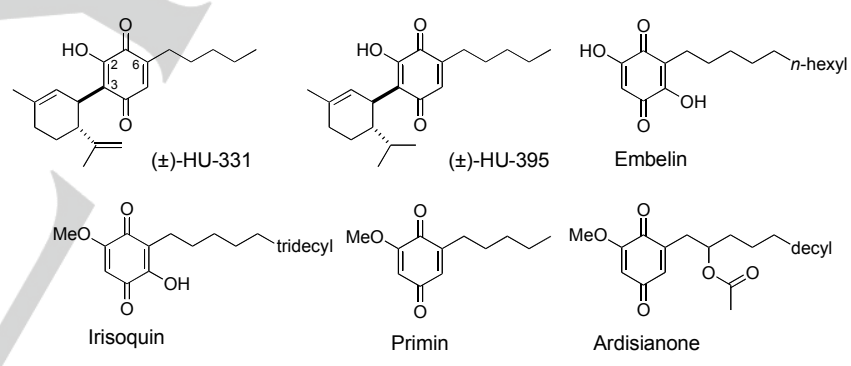

Figure 1. Some monocyclic 1,4-benzoquinone anti-cancer agents.

The close structural relationship (Scheme 3) of HU-331 to cannabidiol (CBD), from which HU-331 can be obtained solely by oxidation, ${ }^{[21]}$ invites the question as to whether cannabinoids can possess anti-cancer activity. Recently, cannabinoids have been shown to inhibit tumour growth and angiogenesis, and to induce apoptosis, ${ }^{[25-27]}$ notably in hormone-sensitive prostate cancers. ${ }^{[7]}$ Cannabidiol can prevent metastasis of breast cancer, possibly by suppressing the activity of the gene Id $-1 .{ }^{[28]} \mathrm{A}$ recent study concluded that 5-hydroxycannabidiol and HU-331 inhibit both the $\alpha$ - and $\beta$ forms of topoisomerase II. ${ }^{[29]} \Delta^{9}$-Tetrahydrocannabinol inhibits the growth and metastasis of lung cancer cell lines and prevents the growth of Lewis lung adenocarcinoma by inhibiting DNA synthesis. ${ }^{[25,30]}$ Cannabinoids comprise a diverse class of compounds that interact with a number of 
molecular targets including the endocannabinoid-1 and -2 receptors and the vanilloid receptor, ${ }^{[31]}$ although their anticancer mechanisms are not fully understood.

In the search for new anti-cancer agents containing a quinone ring, cannabinoid quinones were considered to be a suitable class since the structural motif affords in vitro and in vivo anti-cancer potency, drug-likeness and, especially, as is the case for HU-331, the potential for little or no cardiac toxicity or myelotoxicity, but with inhibition of angiogenesis. $^{[32]}$ However, HU-331 is too chemically unstable, especially in solution, to be used for cancer therapy. Consequently, aims of the present studies were to identify the anti-cancer pharmacophore latent in HU-331 through the study of structurally related monocyclic quinones, and to synthesise and identify more potent derivatives than HU-331, preferably with improved stability and other drug-like properties.

\section{Results and Discussion}

\section{Chemistry}

The initial objective was to devise a set of integrated synthetic protocols to cover a wide range of polysubstituted resorcinol derivatives, thereby affording by oxidation novel 2-hydroxy1,4-benzoquinone derivatives encompassing maximised chemical space. Access to alkyl, cycloalkyl, cycloalkenyl and aryl substituents, among others, was required. The main synthetic strategies to substituted 1,4-benzoquinones are depicted in Scheme 1, in which the last step has in common the oxidation of a substituted resorcinol derivative 8 by Frémy's salt (dipotassium nitrosodisulfonate), ${ }^{[3]}$ in an aqueous buffer of $\mathrm{KH}_{2} \mathrm{PO}_{4},{ }^{[34]}$ giving the desired corresponding quinone $\mathbf{9}$, a means of accessing the quinones which was found in the present study to be both convenient and widely applicable.

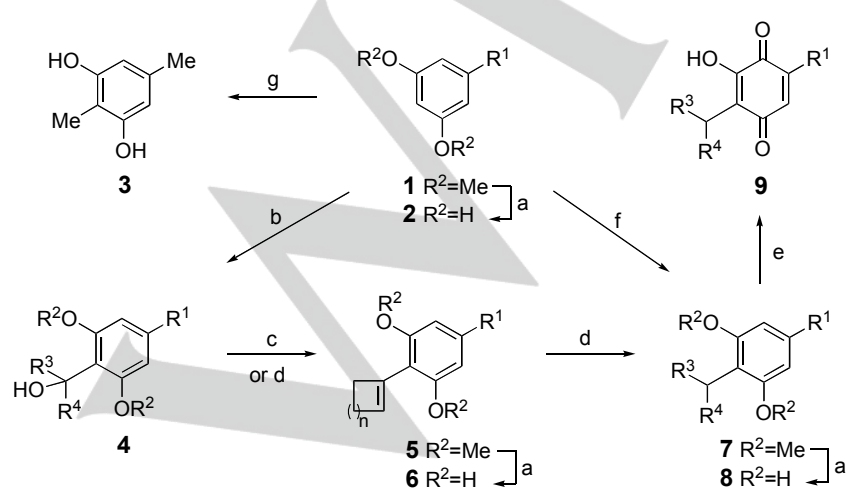

Scheme 1. Synthetic routes to monocyclic 2-hydroxy-1,4-benzoquinones. Reagents and conditions: (a) $\mathrm{BBr}_{3}$ (3 equiv) $\mathrm{CH}_{2} \mathrm{Cl}_{2},-78{ }^{\circ} \mathrm{C}, 10$ min then $20{ }^{\circ} \mathrm{C}, 1 \mathrm{~h}$; (b) $n$-BuLi $\left(1.1\right.$ equiv.), THF, $0{ }^{\circ} \mathrm{C}$ then cyclic ketone, $0{ }^{\circ} \mathrm{C}, 30 \mathrm{~min}$ then $20^{\circ} \mathrm{C}, 18 \mathrm{~h}$; (c) TFA, $\mathrm{CH}_{2} \mathrm{Cl}_{2}$; (d) TFA, $\mathrm{CH}_{2} \mathrm{Cl}_{2}$ then $\mathrm{Et}_{3} \mathrm{SiH}$; (e) Frémy's salt (3.5-10 equiv.), $\mathrm{KH}_{2} \mathrm{PO}_{4}$, aq. acetone; (f) cycloalkenol and CSA (0.1 equiv.), $\mathrm{CH}_{2} \mathrm{Cl}_{2}$ or $\mathrm{BF}_{3}$. $\mathrm{Et}_{2} \mathrm{O}, \mathrm{CH}_{2} \mathrm{Cl}_{2}$; (g) $n$-BuLi, THF then alkyl iodide.

Where feasible, Friedel-Crafts alkylation at the 2-position of resorcinols 2 was the most succinct and hence the preferred route, and was successful with various allylic cycloalkenols. To explore the viability of the Friedel-Crafts route as a general strategy, olivetol was reacted with 1methylcyclohex-2-en-1-ol, ${ }^{[35]}$ in the presence of $\mathrm{BF}_{3} . \mathrm{Et}_{2} \mathrm{O}$ as previously described; ${ }^{[36]}$ in our hands, only a very low yield of $8 p$ was obtained (Table 1, entry 1 ). Although a freshly supplied sample of alumina (entry 2) afforded an improved result, $\mathbf{8 p}$ was accompanied by its cyclised derivative (Table 1 ), as an inseparable mixture. Increasing the equivalents of allylic alcohol (1:1 reactants, entry 3 ) and lowering the amount of Lewis acid gave a high yield of the undesired cyclised compound $\mathbf{A}$ which was formed in lower yield when the reaction was carried out at $20{ }^{\circ} \mathrm{C}$ (entry 4 ) but still as a 1:1 mixture of products. Evidently, the basic alumina found in other cannabinoid studies to suppress acidity, ${ }^{[36]}$ and hence minimise subsequent cyclisation, did not prove effective in this pilot reaction.

The overall inconsistency of these results using $\mathrm{BF}_{3} . \mathrm{Et}_{2} \mathrm{O}$ to perform related condensations to give cannabinoids has also been reported by Kassiou's group ${ }^{[37]}$ although in their work generally satisfactory results were obtained using only a $0.1 \%$ solution of that reagent. In the event, a Brønsted acid approach using 10-camphorsulfonic acid, (CSA), ${ }^{[38]}$ proved much more successful in the present work. In our parallel study of the condensation of the isopropyl cyclohexenol 14 (1.2 equiv.) with olivetol in the presence of CSA (0.1 equiv.) reactant stoichiometry greatly influenced the outcome, an appreciable quantity of olivetol remaining from an initial 1:1 stoichiometry, whereas 8a was obtained in 35\% yield using 1.2 equivalents of 14 , and in $59 \%$ yield using 1.2 equivalents of 14 , no olivetol being detected in the latter case. When a 1:1.5 stoichiometry of 1-methylcyclohex-2-en-1-ol: olivetol was used in the presence of CSA ( 0.1 equiv.) at $20{ }^{\circ} \mathrm{C}$ no olivetol remained, and the required cannabinoid adduct $8 p$ was isolated in $45 \%$ yield (Table 1 , entry 5 ). This condensation protocol (General Procedure D) was found to be effective in fourteen cases of this study, isolation being usually straightforward, and cyclised by-products being absent for reaction periods of 3-6 $\mathrm{h}$. The resulting resorcinol 
derivatives were oxidised with Frémy's salt to give a focused set of closely related congeners of HU-331 (Table 2).

In cases where an aromatic alkylation route (i.e. 2 to 8 ) using a Brønsted acid or a Lewis acid was not efficient,

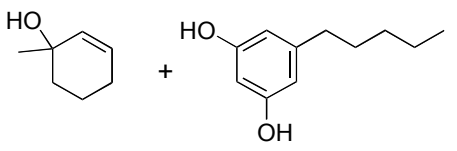

Olivetol

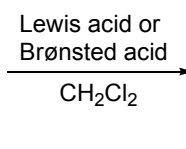

$\mathrm{CH}_{2} \mathrm{Cl}_{2}$ metalation of resorcinol derivatives 1 was generally used, leading to the carbinols 4 which were dehydrated to the

Table 1. Condensation of 1-methylcyclohex-2-en-1-ol with olivetol (1 equiv.) in $\mathrm{CH}_{2} \mathrm{Cl}_{2}{ }^{\text {[a] }}$.

\begin{tabular}{ccccccc}
\hline Entry & $\begin{array}{c}\text { Allylic } \\
\text { alcohol (eq.) }\end{array}$ & Reagent & Additive & $\mathrm{T}\left({ }^{\circ} \mathrm{C}\right)$ & Time $^{[\mathrm{b}]}$ & $\begin{array}{c}\mathbf{8 p}(\%): \\
\mathbf{A}(\%)\end{array}$ \\
\hline 1 & 0.8 & $\mathrm{BF}_{3} . \mathrm{Et}_{2} \mathrm{O}(2.5$ eq. $)$ & $\mathrm{Al}_{2} \mathrm{O}_{3}$ (20 eq.) & reflux & $10 \mathrm{~s}$ & $<5: 0$ \\
\hline 2 & 0.8 & $\mathrm{BF}_{3} . \mathrm{Et}_{2} \mathrm{O}(2.5$ eq. $)$ & $\mathrm{Al}_{2} \mathrm{O}_{3}(20 \text { eq. })^{[\mathrm{b}]}$ & reflux & $10 \mathrm{~s}$ & $25: 25$ \\
\hline 3 & 1.0 & $\mathrm{BF}_{3} . \mathrm{Et}_{2} \mathrm{O}(1.6$ eq. $)$ & $\mathrm{Al}_{2} \mathrm{O}_{3}(20 \text { eq. })^{[\mathrm{b}]}$ & reflux & $10 \mathrm{~s}$ & $0: 89$ \\
\hline 4 & 1.0 & $\mathrm{BF}_{3} . \mathrm{Et}_{2} \mathrm{O}(1.6$ eq. $)$ & $\mathrm{Al}_{2} \mathrm{O}_{3}(20$ eq. $)$ & 20 & 5 min & $31: 31$ \\
\hline $\mathbf{5}$ & $\mathbf{1 . 5}$ & $\mathbf{C S A}(\mathbf{0 . 1}$ eq. $)$ & - & $\mathbf{2 0}$ & $\mathbf{6} \mathbf{h}^{[\mathrm{d}]}$ & $\mathbf{4 5 : 0}$ \\
\hline
\end{tabular}

[a] Percentage of conversion was determined from the ${ }^{1} \mathrm{H}$ NMR spectra of the crude products. [b] For entries $1-3$, a suspension of alumina in a solution of $\mathrm{BF}_{3}$. Et $\mathrm{t}_{2} \mathrm{O}$ in dry $\mathrm{CH}_{2} \mathrm{Cl}_{2}$ was stirred for $15 \mathrm{~min}$, then heated at reflux for $1 \mathrm{~min}$ (entries 1 and 2) or $5 \mathrm{~min}$ (entry 3 ), and then the reactants added. After the reaction time stated the mixture was quenched with saturated aqueous $\mathrm{NaHCO}_{3}$. [c] A new bottle of alumina was used. [d] 1-Methylcyclohex-2-en-1-ol was added dropwise over $3 \mathrm{~h}$ via a syringe pump; then the mixture was stirred for an additional $3 \mathrm{~h}$.

cycloalkenyl derivatives $\mathbf{5}$ which were then reduced with $\mathrm{CF}_{3} \mathrm{CO}_{2} \mathrm{H}-\mathrm{Et}_{3} \mathrm{SiH}$. More usually, and preferably, the sequential dehydration-reduction of alcohols 4 was accomplished in one overall step by addition of TFA followed by $\mathrm{Et}_{3} \mathrm{SiH}$. The resulting methyl ethers 7 were demethylated using $\mathrm{BBr}_{3}$ in dichloromethane to give the corresponding resorcinol derivatives 8 which were oxidised to the target quinones 9. The 2,5dimethylresorcinol derivative $\mathbf{3}$ was prepared by metalation of 1,3-dimethoxy-5-methylbenzene with $n$-BuLi and alkylation with $\mathrm{Mel}$ to give 1,3-dimethoxy-2,5dimethylbenzene in $78 \%$ yield ${ }^{[39,40]}$ followed by demethylation of the latter in $88 \%$ yield using $\mathrm{BBr}_{3}$.

In order to obtain a full range of diversely substituted resorcinols, several synthetic methods were required (Scheme 2). Suzuki reaction of the boronic acid 10 with a cycloalkenyl trifluoromethanesulfonate ('triflate') afforded the 5-substituted cycloalkenyl derivatives 11 and 12 which were reduced to the corresponding 5-substituted cycloalkyl derivatives $\mathbf{1 d}$ and $\mathbf{1 f}$ using ammonium formate and $5 \% \mathrm{Pd}-\mathrm{C}$ in ethanol, and $\mathrm{TFA}-\mathrm{Et}{ }_{3} \mathrm{SiH}$ in $\mathrm{CH}_{2} \mathrm{Cl}_{2}$, respectively. Demethylation of those and other substituted resorcinols was found to be generally satisfactory using $\mathrm{BBr}_{3}$, using a procedure of addition at $-78{ }^{\circ} \mathrm{C}$ (stirred for
$10 \mathrm{~min}$ ) followed by warming to $20^{\circ} \mathrm{C}$ over $1 \mathrm{~h} .{ }^{[41]}$ The 5 (2-indenyl) resorcinol ether 16, prepared in $59 \%$ yield by Suzuki coupling of boronic acid 10 with 2-bromo-1Hindene, was reduced to the indanyl derivative 1e using ammonium formate and 5\% Pd-C in ethanol.

5-Substituted resorcinols usually underwent FriedelCrafts alkylation mainly or exclusively at the 2-position, as might be expected on grounds of a combination of electronic effects of the two ortho-phenolic $\mathrm{OH}$ groups, together with steric hindrance of approach to the 4- and 6positions provided by the 5-substituent. However, the only isolated product of the condensation of resorcinol with 14 was the 4-substituted derivative $\mathbf{8 j}$ (18\%). Also, in the condensation of 13 with 14 , an appreciable quantity of the 4-substituted product $\mathbf{8 I}$ was isolated. Those results are consistent with observations on the condensation of methylcyclohex-2-en-1-ol with orcinol (5-methylresorcinol) in $\mathrm{CH}_{2} \mathrm{Cl}_{2}$ in the presence of $\mathrm{BF}_{3}$. $\mathrm{Et}_{2} \mathrm{O}$, in which the main product was that of alkylation at the 4-position. ${ }^{[42]}$ Conversely, from olivetol (larger C-5 substituent) the main product was the result of solely 2-alkylation (e.g. Scheme 4).

With the principal reactions for the synthesis of $\mathrm{HU}-331$ analogs now in hand, consideration was given to a total 
synthesis of the cannabinoid HU-331. The natural product HU-331 has usually been prepared by aerial oxidation of cannabidiol (CBD), obtained from plant sources. ${ }^{[21]} \mathrm{A}$ pure source of HU-331 was required as a benchmark against which to measure biological activity of the novel quinones here reported. Accordingly, a synthetic route was sought, preferably using the optimised Friedel-Crafts alkylation<smiles>[R]Oc1cc(O[R])cc(C2CCCC2)c1</smiles><smiles>CC1=C[C@H](O)C(C(C)C)CC1</smiles><smiles>[R]Oc1cc(O[R])cc(C2Cc3ccccc3C2)c1</smiles>

16

$( \pm)-14$

$1548 \%$

8I $38 \%$

1e $\mathrm{R}=\mathrm{OMe}$
2e $\mathrm{R}=\mathrm{H}$

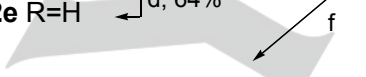

OR

$\left.\begin{array}{l}\text { 1b R=OMe } \\ \text { 2b R=H }\end{array}\right]$ d, $56 \%$

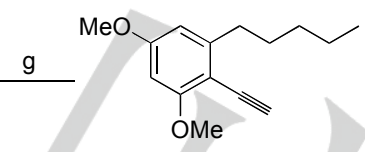

18

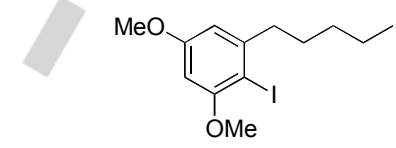

17<smiles>[3H][PH3]</smiles><smiles>[R]Oc1cc([R])c(-c2ccccc2)c(CCCCC)c1</smiles>

1c $\mathrm{R}=\mathrm{OMe}$

2c $\mathrm{R}=\mathrm{H}] \mathrm{d}, 75 \%$

Scheme 2. Regioselective synthesis of substituted resorcinol derivatives: Reagents and conditions: (a) For 1d: cycloalkenyl triflate (0.9 equiv.), $\mathrm{Ph}{ }_{3} \mathrm{P}(1 \mathrm{~mol} \%)$,

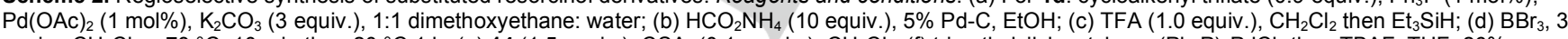
equiv., $\mathrm{CH}_{2} \mathrm{Cl}_{2},-78{ }^{\circ} \mathrm{C}, 10$ min then $20{ }^{\circ} \mathrm{C}, 1 \mathrm{~h}$; (e) 14 (1.5 equiv.), CSA (0.1 equiv.), $\mathrm{CH}_{2} \mathrm{Cl}_{2}$; (f) trimethylsilylacetylene, $\left(\mathrm{Ph}{ }_{3} \mathrm{P}\right){ }_{2} \mathrm{PdCl}{ }_{2}$ then TBAF, $\mathrm{THF}, 26 \%$ $26 \%$ (2 steps); (g) $\mathrm{H}_{2}, \mathrm{Pd}-\mathrm{C}, \mathrm{MeOH}, 59 \%$; (h) $\mathrm{PhB}(\mathrm{OH})_{2},\left(\mathrm{Ph}_{3} \mathrm{P}\right)_{4} \mathrm{Pd}, \mathrm{Na}_{2} \mathrm{CO}_{3}$, aq., 1,2-dimethoxyethane, $69 \%$.

route described above. In our hands, a direct approach to $( \pm)$-CBD by the condensation of olivetol with isopiperitenol in the presence of CSA afforded an inseparable mixture of $( \pm)$-cannabidiol (CBD) and $( \pm)-\Delta^{9}$-tetrahydrocannabidiol (THC), the latter formed by acid-catalysed cyclisation of the former. Instead, olivetol was condensed with the diol 19 using the Friedel-Crafts conditions optimised as above; pleasingly, the desired triol $\mathbf{2 0}$ was obtained in $\mathbf{7 3 \%}$ yield (Scheme 3). Although this triol has been reported to cyclise to THC and its derivatives, ${ }^{[43]}$ to the best of our knowledge it has not been used to synthesise CBD. Initially, protection of the phenolic $\mathrm{OH}$ groups by tosylation and also by triflation, with concomitant elimination of the carbinol was attempted, but in neither case could efficient $O$ - deprotection be achieved. However, mesylation of $\mathbf{2 0}$ in the presence of $\mathrm{Et}_{3} \mathrm{~N}$ also induced the desired elimination to the isopropenyl group, and subsequent removal of the aromatic mesylate groups using MeLi afforded ( \pm )-CBD in satisfactory yield. ${ }^{[44]}$ Notably, oxidation of $( \pm)$-CBD using Frémy's salt afforded ( \pm )-HU-331 in $92 \%$ yield. This use of Frémy's salt compares very favourably with the yield of $20 \%$ achieved in the early oxygenation of cannabidiol in aqueous $5 \% \mathrm{KOH}$ to give $\mathrm{HU}-331 .{ }^{[21]}$ 
<smiles>CCCCCc1cc(O)cc(O)c1</smiles>

Olivetol

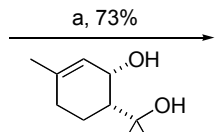

$( \pm)-19$
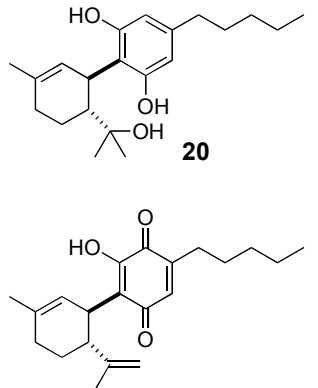

( \pm -HU-331

Scheme 3. A convergent synthesis of ( \pm )-cannabidiol and $( \pm)$-HU-331 via the triol 20. Reagents and conditions: (a) 19 (1.5 equiv.), CSA (0.1 equiv.), $\mathrm{CH}_{2} \mathrm{Cl}_{2}, 20^{\circ} \mathrm{C}, 3 \mathrm{~h}$; (b) $\mathrm{MsCl}$ (6.0 equiv.), $\mathrm{Et}_{3} \mathrm{~N}$ (10 equiv.), $\mathrm{CH}_{2} \mathrm{Cl}_{2} ; 0^{\circ} \mathrm{C}, 1$ $\mathrm{h}$, then $20^{\circ} \mathrm{C}, 16 \mathrm{~h}$; (c) MeLi (23 equiv.), THF, $0^{\circ} \mathrm{C}, 1 \mathrm{~h}$; (d) Frémy's salt (5.5 equiv.), $\mathrm{KH}_{2} \mathrm{PO}_{4}$ (2.3 equiv.), aq. acetone, $20^{\circ} \mathrm{C}, 16 \mathrm{~h}$.<smiles>[R20]c1cc(CCCCC)cc([R])c1[C@H]1C=C(C)CC[C@H]1C(=C)C</smiles>

$21 \mathrm{R}=\mathrm{Ms}, \mathrm{c}, 70 \%$ $\stackrel{\text { d, } 92 \%}{\longrightarrow}$

Table 2. Inhibition of Topoisomerase II by Substituted Monocyclic Quinones. ${ }^{\text {[a,b] }}$ 


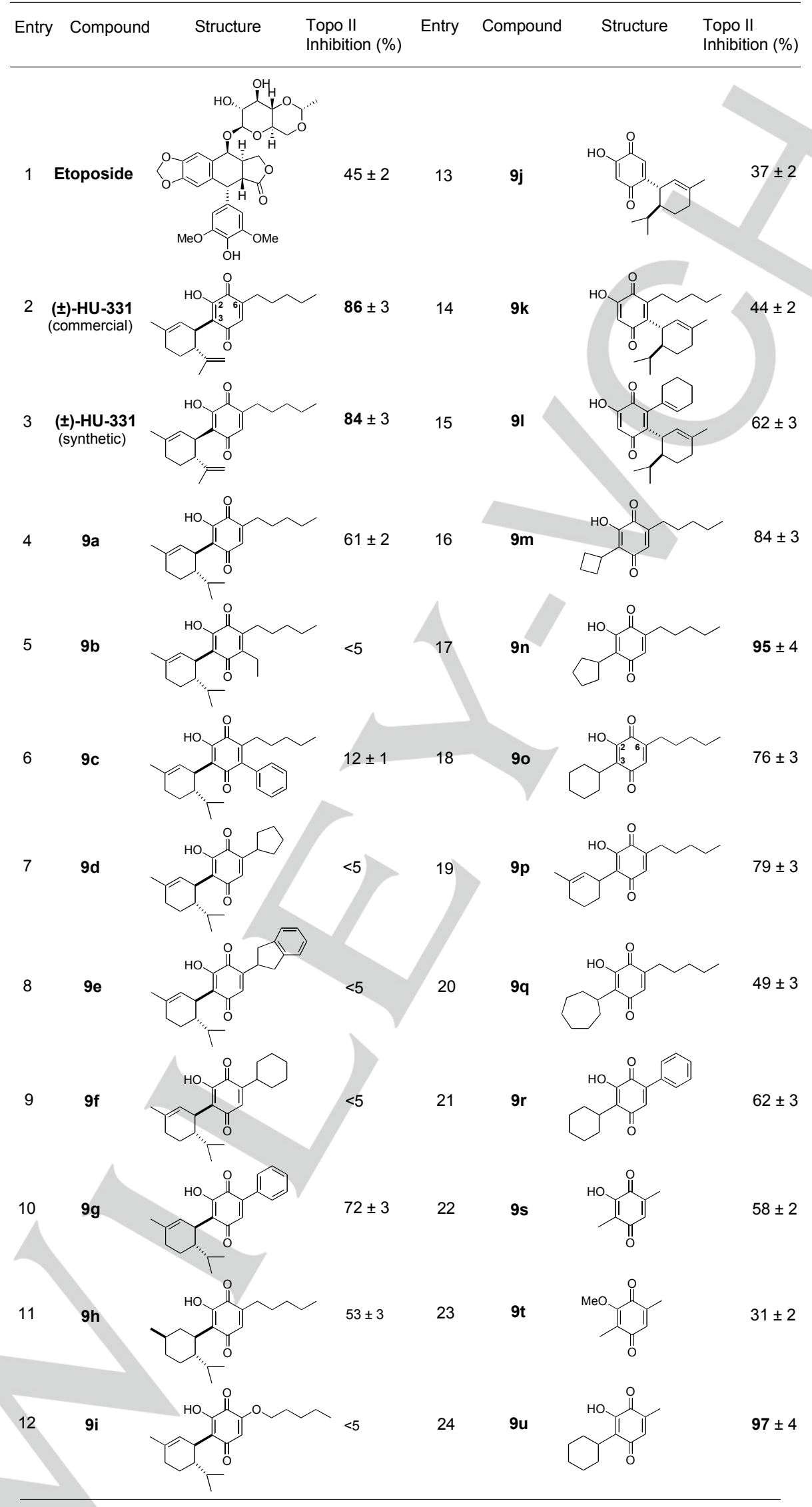

[a] Inhibition at $80 \mu \mathrm{M}$ concentration of test compound. [b] Average of triplicate runs \pm SEM. 
Regioselectivity of the Friedel-Crafts condensation reactions involving resorcinol and its derivatives was established by NMR spectroscopy. For example, reaction of resorcinol at the 4-position giving $9 \mathbf{j}$ was established from the singlet in the ${ }^{1} \mathrm{H}$ NMR spectrum for the isolated C-3 hydrogen atom at $\delta 6.09$ and the four-bond coupling constant of $0.7 \mathrm{~Hz}$ for the C-6 hydrogen atom at $\delta 6.57$. Consideration of the number of lines in the ${ }^{13} \mathrm{C} N M R$ spectra of the resorcinol derivatives 8 was also often diagnostic of the position of condensation (i.e. C2- versus C-4).

In the ${ }^{1} \mathrm{H}$ NMR spectrum of the quinones 9 the transdiaxial coupling constant of approx $11.5-12.0 \mathrm{~Hz}$ confirmed the trans configuration of the isopropyl (or isopropenyl) substituent with the 1,4-benzoquinonyl group. Although the relative configuration of the methyl group in $\mathbf{8 h}$ and $\mathbf{9 h}$ could not be deduced from NMR data owing to overlapping multiplets in the relevant regions, only one diastereoisomer was detected, and by analogy with the hydroborationoxidation of (+)-2-carene to give (-)-2-isocaranol (92\%), ${ }^{[45]}$ hydroboration on the face opposite to the bulky isopropyl group would be expected, affording the triequatorially substituted stereoisomer $\mathbf{8 h}$, and hence $\mathbf{9 h}$.

\section{In vitro inhibition of topoisomerase II by monocyclic quinones}

Several studies have confirmed that the monocyclic quinone HU-331 inhibits the relaxation activity of topoisomerase II, ${ }^{[19,20,24,46]}$ and is highly selective for this isozyme. Both the commercial HU-331 and our synthetic samples of $\mathrm{HU}-331$ (concentration range tested from 0.3$100 \mathrm{mM}$ ) were found not to increase the amount of nicked DNA in a topoisomerase I DNA cleavage assay, (data not shown) in accord with previous studies. ${ }^{[20]}$ Equally, no evidence was found for the intercalation of HU-331 (concentration range tested from $0.03-100 \mathrm{mM}$ ), as assessed by a DNA intercalation assay using ethidium bromide as the control. For the topoisomerase II DNA relaxation assay (Figs. 2-4) a reliable system involved preincubation of the test compounds with human toposomerase II (Affymetrix) for $10 \mathrm{~min}$, and a relaxation buffer containing ATP $(10 \mathrm{mM})$ and $\mathrm{MgCl}_{2}(0.1 \mathrm{M})$, giving full inhibition between 27-270 mM and some inhibition at $0.27 \mathrm{mM}$. First, under those conditions, the same concentrations of commercial HU-331 and synthetic ( \pm )-
HU-331 were shown to perform in the same way in the topoisomerase Il $\alpha$ assay (Fig. 2). Secondly, a suitable benchmark concentration of $80 \mathrm{mM}$ was established for the evaluation of the series of monocyclic quinones (Table 2). At that concentration, significant amounts of both supercoiled plasmid DNA and relaxed topoisomeric DNA were observed in the histograms and the corresponding pixel intensities of ethidium bromide fluorescence could be accurately measured using ImageJ software (Fig. 3).

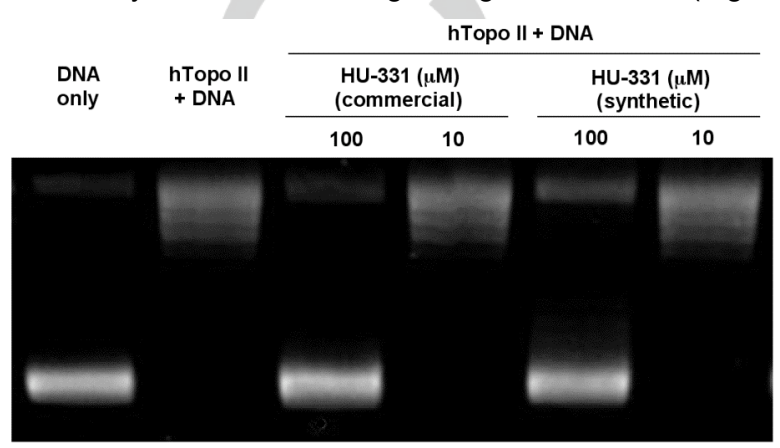

Figure 2. Comparison of the effect of commercial versus synthetic samples of $\mathrm{HU}-331$ pre-incubated with human topoisomerase II for 10 minutes followed by addition of supercoiled plasmid DNA.

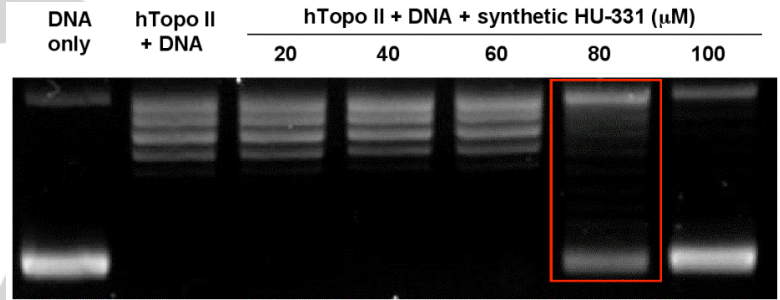

Figure 3. Human topoisomerase II-induced relaxation of supercoiled plasmid DNA in the presence of a range of concentrations of synthetic HU331 (pre-incubated with the enzyme for 10 minutes).

\section{Quinone structure-activity relationship based on} topoisomerase Il $\alpha$ inhibition

In our hands, synthetic racemic HU-331 and commercial HU-331 were also found to be equipotent in the topoisomerase Il $\alpha$ DNA relaxation assay (Table 2). Additionally, enantiomers of HU-331 have been reported to be equipotent against a variety of cancer cell lines. ${ }^{[20]}$ As with a set of bisdioxopiperazine catalytic inhibitors of topoisomerase II (i.e. inhibitors of one or more steps in the enzyme-DNA ligation/deligation/strand cleavage cycle) whose enantiomers showed equipotency in respect of both enzyme inhibition and cellular cytotoxicity, ${ }^{[46]}$ a similar explanation can be advanced for the quinone HU331 , namely that the site of binding to topoisomerase Il $\alpha$ is either sufficiently large or sufficiently flexible to accommodate each enantiomer equally well. 
Of the trisubstituted $\mathrm{HU}-331$ analogs $9 \mathbf{a}$ and $9 \mathbf{c}-9 \mathbf{h}$, in which the terpenoid unit had been retained (or hydrogenated in the cases of $9 \mathrm{a}$ and $\mathbf{9 h}$ ) each of this series of compounds showed some inhibition, but none greater than or equal to HU-331 (Table 2). Saturation of the isopropenyl group of $\mathrm{HU}-331$ lowered the inhibition (61\% for 9a, c.w. $86 \%$ for HU-331). Complete saturation of the terpenoid unit lowered the inhibition further $(53 \%$ for 9h). However, removal of the isopropenyl group in HU331 resulted in only a small loss of inhibition ( $79 \%$ for $9 p)$, suggesting that the isopropenyl group is not essential for potent inhibition of topoisomerase Il $\alpha$. Although the fully reduced terpenoid unit in $\mathbf{9} \mathbf{h}$ showed the lowest potency within the series of terpenoid derivatives studied, this compound illustrated that a 2-cyclohexyl ring can be compatible with good inhibition. Following this observation, the subset of saturated cycloalkyl quinones $\mathbf{9 m - 9 o}$ and $\mathbf{9 q}$ was synthesised; not only was good-to-excellent inhibition of topoisomerase Il $\alpha$ observed, but in the set of 6 - $n$-pentyl quinones synthesised, 90 was the only crystalline compound, and also showed much greater stability when kept as a solution in DMSO- $\mathrm{d}_{6}$ at $20{ }^{\circ} \mathrm{C}$, with little decomposition after 8 days (90\% of initial concentration), in contrast to HU-331 which had almost completely decomposed $(10 \%$ of initial concentration, Fig. 6 , Supplementary Information); indeed, after 2 days, more than $50 \%$ of HU-331 had decomposed.

Within the terpenoid series described above, variation of the 6-substituent was examined; conformational restriction by annulation to give a five-membered ring (9d) or six-membered ring (9f) removed all significant inhibition, as did replacement of the 6 - $n$-pentyl chain by a 2 -indanyl group (9e) or an $n$-butyloxy group (9i). In the latter case, electronic factors may play a role by lowering the electrophilicity of the quinone ring, and in the former cases, increased steric hindrance appears to be the likely contributor. In contrast, a 6-phenyl substituent retained considerable inhibitory potency $(72 \%$ for $9 \mathrm{~g})$, as also did an unadorned 3-cyclohexyl substituent (62\% for 9r), perhaps because of the planarity afforded by the extended $\mathrm{sp}^{2}$-character of the 6-phenyl substituent whose planarity may permit $\pi$-stacking with a nearby aromatic amino acid residue.

Within the C-5 substituted congeners, the tetrasubstituted quinones $\mathbf{9 b}$ and $\mathbf{9 c}$ showed no significant inhibition, consistent with a proposed mechanism involving conjugate addition of a toposiomerase II residue to an unsubstituted position on the quinone ring; ${ }^{[47,48]}$ residues Cys392 and Cys405 have been identified as significant for addition to $p$-benzoquinone. ${ }^{[48]}$ In contrast, quinones $\mathbf{9 k}$ and $9 \mathbf{I}$ showed moderate and good potency, respectively, compared with $\mathrm{HU}-331$. If the novel topoisomerase $\| 1 \alpha$ inhibitors $9 \mathbf{j}$, $9 \mathbf{k}$ and $9 \mathbf{l}$, which all possess a 5-substituent, act in a way similar to the parent compound HU-331, conjugate addition presumably occurs at C-3. This requirement for an unsubstituted (Michael acceptor) site on the quinone ring was further probed by examining the effect of $\mathbf{9 d}$ and $\mathbf{9 b}$ at $200 \mathrm{mM}$ on topoisomerase Il $\alpha$ (Fig. 4); at this higher concentration, 9d showed complete inhibition, but without the formation of observable topoisomers. Conversely, the tetrasubstituted quinone $9 \mathrm{~b}$ showed no inhibition. Those observations are consistent with covalent adduct formation being a principal mode by which monocyclic quinones including HU-331 can act on human topoisomerase $\| \alpha,{ }^{[24,48,49]}$ and which recently has been proposed to involve interference of the quinone with the $\mathrm{N}$-terminal domain, thereby preventing the N-terminal clamp from capturing DNA. ${ }^{[24,29,48]}$ The fully substituted quinone ring of $\mathbf{9 b}$ retards or prevents adduct formation.

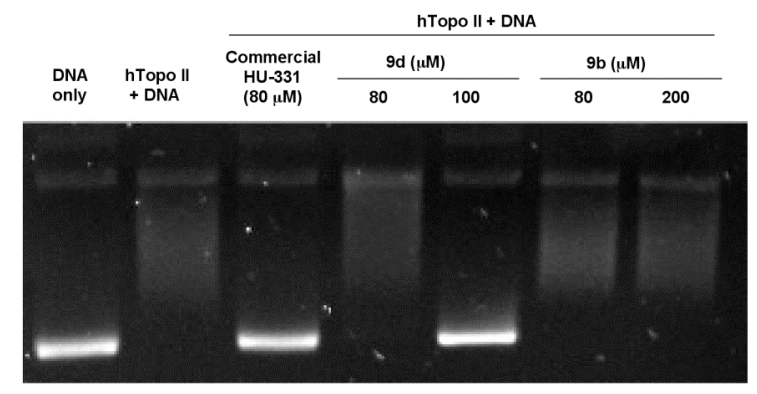

Figure 4. Human topoisomerase II-induced relaxation of supercoiled plasmid DNA in the presence of (a) the trisubstituted quinone 9d and (b) the tetrasubstituted quinone $\mathbf{9 b}$.

The above survey of topoisomerase Il $\alpha$ inhibition as a function of variations in substitution suggested further investigation of 3-cycloalkyl derivatives of 2-hydroxy-6-npentyl-1,4-benzoquinone, particularly since 90 had been shown to have much greater stability than HU-331. Initially, and to identify a reference for acyclic substituents, quinone 9s was prepared and evaluated; its considerable potency $(58 \%)$ was diminished upon O-methylation $(31 \%$ 
for 9t), confirming the need for the unsubstituted hydroxy group. Introduction of a cyclohexyl group at C-3 afforded the most potent compound in the quinone series, showing $97 \%$ inhibition at $80 \mu \mathrm{M}$, and hence that an $n$-pentyl chain is not a requirement for potent inhibition of topoisomerase Ila. Variation of the ring size of the C-3 cycloalkyl substituent showed that cyclopentyl conferred the greatest enzyme inhibition ( $95 \%$ for $9 \mathbf{n}$ ), being more potent than HU-331 (86\%). The cycloheptyl congener 9q was the least potent $(49 \%$ inhibition) of the set $5 \mathrm{~m}-9 \mathrm{r}$. The cyclohexenyl derivative $9 p$ (78\% inhibition) was not significantly more potent than the 3-cycloalkyl quinone 90 (76\%).

The cyclohexyl ring present in the corresponding compound 90 confers markedly greater stability as well as crystallinity, an observation which helped focus the search for potency a set of quinones $\mathbf{9}$ that contained a simplified and saturated 3-cycloalkyl unit, compared to the terpenoid unit present in HU-331. Since compounds $9 \mathbf{n}, \mathbf{9 o}$ and $\mathbf{9 u}$ were more potent inhibitors of topoisomerase Il $\alpha$ than $\mathrm{HU}$ 331 , as well as being considerably more stable, they were tested against a number of cancer cell lines to determine whether the potent enzyme assay results would be accompanied by antiproliferation in whole cell assays.

\section{Cytotoxic effects of monocyclic quinones}

Inhibitory activity against proliferation of the prostate cancer cell line DU-145 was measured using an XTT assay with continuous exposure for 72 h (Table 3); compared to $\mathrm{HU}-331$, four compounds were considerably more potent inhibitors. Of the compounds assayed that contain a terpenoid-like substituent, the isopropyl derivative $9 \mathrm{a}$ and the corresponding system $9 \mathrm{~h}$ with a saturated terpenoid system were of similar potency, both being more potent than $\mathrm{HU}-331$, implying that a more saturated terpenoid skeleton can be an improvement. Compared to $9 \mathbf{a}$, conformational restriction of the 6substituent to cyclopentyl, as in $\mathbf{9 d}$, further increased the inhibitory potency two-fold. Of similar or greater potency against DU-145 cell proliferation was the 3-cyclohexyl derivative 9o. The other derivatives showed medium to low inhibitory activity, despite $9 p$ and $9 u$ showing, respectively, similar and greater potency than HU-331 in the topoisomerase Il $\alpha$ assay. This can be accounted for by a lack of sufficient lipophilicity in the 6-substituent (9s-
$9 w)$, although that is partly compensated for by the 3cyclohexyl substituent in $9 \mathbf{u}$. That $\mathbf{9 w}$ was by far the least active compound evaluated against DU-145 cell line proliferation is consistent with the absence of any lipophilic group at both C-3 and C-6 (hence very low potency), despite the presence at C-6 in $9 w$ of the complete terpenoid group that is found in HU-331. The main factor accounting for the difference in cellular inhibitory potency is probably the difficulty of the much more polar $9 w$ in traversing the DU-145 cell membrane, as expected from the markedly different lipophilicities (HU$331 \mathrm{cLog} \mathrm{P}=6.14$ versus $9 \mathrm{w}$ cLog $\mathrm{P}=3.51$ ). However, the lower potency of 2-methoxy compounds compared to their 2-hydroxy analogs, for both enzyme inhibition and DU-145 cell line anti-proliferation cannot be accounted for in terms of lipophilicities (9s cLogP = 0.99 and 9t cLogP = 1.15), and is ascribed to the hydroxy group acting as a hydrogen bond donor.

A selection of the more potent compounds was then evaluated for inhibition of proliferation of Jurkat human acute T cell leukaemia and Raji human lymphoma cell

Table 3. Antiproliferation $\mathrm{IC}_{50}(\mu \mathrm{M})$ data monocyclic quinones. ${ }^{[a]}$

\begin{tabular}{|c|c|c|c|}
\hline $\begin{array}{l}\text { Cell line: } \\
\text { Compound }\end{array}$ & DU-145 & Jurkat & Raji \\
\hline$( \pm)-H U-331$ & $9.15 \pm 0.57$ & $1.30 \pm 0.20^{[20]}$ & $0.61 \pm 0.05^{[21]}$ \\
\hline $9 a$ & $5.45 \pm 0.26$ & $N D^{[b]}$ & ND \\
\hline $9 d$ & $2.4 \pm 0.60$ & ND & ND \\
\hline $9 \mathrm{~h}$ & $5.2 \pm 0.20$ & ND & ND \\
\hline $9 n$ & $13.7 \pm 0.60$ & $2.37 \pm 0.10$ & $5.27 \pm 0.25$ \\
\hline 90 & $2.05 \pm 0.10$ & $0.29 \pm 0.02$ & $\mathbf{0 . 6 8} \pm 0.03$ \\
\hline $9 p$ & $20.1 \pm 4.4$ & ND & ND \\
\hline $9 s$ & $27.8 \pm 4.3$ & ND & ND \\
\hline $9 t$ & $40.6 \pm 2.9$ & ND & ND \\
\hline $9 u$ & $12.8 \pm 0.52$ & $0.42 \pm 0.02$ & $1.45 \pm 0.06$ \\
\hline $9 v$ & $19.0 \pm 0.23$ & ND & ND \\
\hline $9 w$ & $57.0 \pm 15.5$ & ND & ND \\
\hline
\end{tabular}

[a] Data from cell viability (ATP) assay for compounds $\mathbf{9 n}, \mathbf{9 o}$ and $\mathbf{9 u}$; all other data for DU-145 from XTT assay. Average of triplicate runs \pm SEM. [b] ND = not determined.

lines (Table 3). Comparison of $9 \mathrm{n}$ with 90 shows that 3cyclohexyl ring confers nearly an eight-fold greater inhibitory activity across the three cell lines studied than a 3-cyclopentyl ring. The 3-cyclohexyl derivative $9 \mathbf{u}$ also 
showed good-to-excellent potency. The most potent compound was identified as 90 , showing significantly improved potency in two of the three cell lines studied, including submicromolar potency in two of the cell lines.

Simplification of chemical structure by removal of metabolically active unsaturation led to greater overall potency than $\mathrm{HU}-331$ as well as greatly increased in vitro stability.

Some differences were observed in the relative inhibition of topoisomerase Il $\alpha$ versus inhibition of cell line proliferation. For example, a terpenoid isopropenyl group (HU-331, 86\%) conferred greater potency than the corresponding isopropyl group (9a, 61\%), whereas in the DU-145 cell line assay the isopropenyl group in HU-331, $86 \%$ ) conferred 1.7 -fold less potency than the isopropyl group in 9a. Also, absence of the isopropenyl group in HU-331 (86\% inhibition of topoisomerase Il $\alpha$ ) gave only a small loss in enzyme inhibition (79\% for $9 p$ ), whereas compared to $\mathrm{HU}-331$ inhibition of $\mathrm{DU}-145$ cell proliferation by $9 p$ was more than halved. A third difference was seen for $9 u$, the most potent inhibitor of all the novel quinones tested (and more potent than HU-331), but which was less potent than HU-331, 9a, 9d, 9h and 90 in the DU-145 cell line assay. Fourthly, the results of the topoisomerase II $\alpha$ assay showed that decreasing the 3-cycloalkyl ring size from 7 to 6 to 5 increased potency (9n having the secondhighest inhibition of $95 \%$ at $80 \mu \mathrm{M}$ of all compounds tested in the enzyme assay). Conversely, in the cell line assays, decreasing the ring size was detrimental to inhibition of proliferation, the 3-cyclopentyl derivative 9n exhibiting over 6-fold less potency than the 3-cyclohexyl derivative 9o. Thus, while the greater requirement for lipophilicity in whole cell assays compared to an in vitro enzyme assay must be considered, and is expected on account of cell membrane permeability, overall the relative potency of whole cell inhibitory activity still shows some significant differences with the relative potency of the topoisomerase Il $\alpha$ assay, and may indicate that inhibition of topoisomerase $I l \alpha$ (e.g. for 9o) is not the only relevant molecular target; ${ }^{[50]}$ further studies are indicated.

\section{Conclusions}

New syntheses of cannabidiol and ( \pm )-HU-331 are reported herein. General synthetic approaches to a wide variety of substituted derivatives of 1,4-benzoquinone have been described, the shortest employing a FriedelCrafts alkylation of a resorcinol derivative followed by oxidation to the quinone using Frémy's salt. New derivatives of 1,4-benzoquinone have been identified as more potent than HU-331, a potent natural product anticancer agent showing no significant cardiotoxicity. Novel potent inhibitors of human topoisomerase $I l \alpha$ and of proliferating cancer cell lines were identified, including 9a, 9d, 9h and especially 9o which showed a greater than four-fold inhibition of the DU-145 prostate cancer cell line than $\mathrm{HU}-331$, as well as submicromolar inhibitory potency against both Jurkat human acute $\mathrm{T}$ cell leukaemia and Raji human lymphoma cell lines. The simplified analogs, including 9o, showed much greater in vitro stability compared to HU-331, ascribed to the absence of chemically reactive groups (which in HU-331 are likely sites of metabolism).

Anti-cancer properties here identified were correlated with structure, which indicated clear directions for further optimisation, especially variation in 6-alkyl substitutents; 6-aryl and 3-(4-substituted)-cyclohexyl derivatives may also be promising areas of chemical space. This preliminary structure-activity profile identified for these quinones should facilitate the discovery of new, drug-like monocyclic quinone anti-cancer agents with low cardiotoxicity (partly attributable to minimal ROS production), unlike many fused quinone systems, especially the clinically important anthracyclines whose use is constrained by severe and dose-limiting cardiotoxicity.

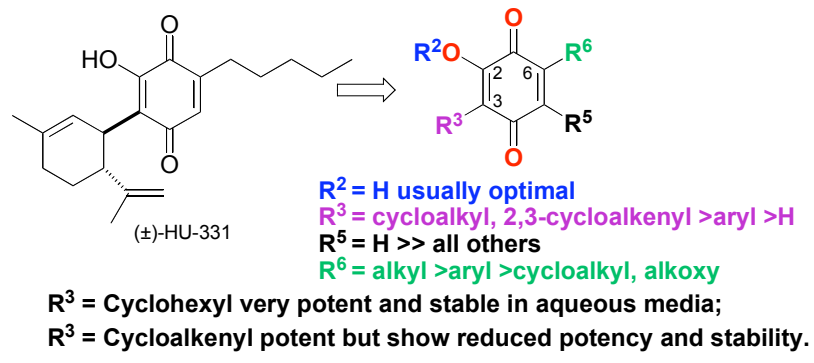

Figure 5. Correlation of substituted hydroxy-1,4-benzoquinones with anticancer properties identified.

Although inhibition of human topoisomerase $\mathrm{Il} \alpha$ is a confirmed and likely major target, several observations indicate that some monocyclic quinone inhibitors act on at least one other molecular target, not revealed by the present study. Based on broad-spectrum activity against 
multiple cell lines, its crystallinity and its greatly increased stability compared to HU-331, compound $\mathbf{9 o}$ is suitable as a probe to elucidate uncharted quinone chemical biology, and also as the basis for next-generation antiproliferative hydroxyquinones possessing minimal cardiotoxicity compared to existing clinical quinone anti-cancer agents.

\section{Experimental section}

\section{Instruments and Methods}

Reactants and reagents were used as received. Commercial HU-331 was purchased from Abcam. Compound homogeneity was monitored by ascending thin-layer chromatography, performed on Merck $0.2 \mathrm{~mm}$ aluminium-backed silica gel $60 \mathrm{~F}_{254}$ plates and visualised using ultraviolet irradiation ( $254 \mathrm{~nm}$ ) or by using aqueous alkaline potassium permanganate. Flash column chromatography was performed using Merck silica gel 60 of particle size $33-70 \mathrm{~mm}$. Evaporation refers to the removal of solvent under reduced pressure. Melting points were determined using an Optimet apparatus and are uncorrected. Infrared (IR) spectra were recorded on a Bruker alpha FT-IR spectrometer using neat samples. ${ }^{1} \mathrm{H}$ and ${ }^{13} \mathrm{C}$ NMR spectra (respective operating frequencies of $500 \mathrm{MHz}$ and $125 \mathrm{MHz}$ ) were obtained using a Bruker AM-500 spectrometer in a variety of solvents and a residual non-deuterated solvent peak as the internal reference: $\mathrm{CDCl}_{3}\left(\delta_{\mathrm{H}}=7.26 \mathrm{ppm}, \delta_{\mathrm{C}}=77.0 \mathrm{ppm}\right)$, DMSO $\left(\delta_{\mathrm{H}}=2.50 \mathrm{ppm}, \delta_{\mathrm{C}}=39.5 \mathrm{ppm}\right) \mathrm{CD}_{3} \mathrm{OD}\left(\delta_{\mathrm{H}}=3.31 \mathrm{ppm}\right.$, $\left.\delta_{\mathrm{C}}=49.0 \mathrm{ppm}\right)$. Mass spectra were obtained on a Fisons VG70-SE mass spectrometer or Thermo Finnigan MAT900xp instrument using electrospray ionisation (ESI), electron ionization $(\mathrm{EI})$ or chemical ionization $(\mathrm{Cl})$.

\section{Supplementary data}

Preparation and spectral data of compounds are given in the Supporting Information.

General procedure A (demethylation of 1,3dimethoxyarenes): To a stirring solution of the 1,3dimethoxyarene $(0.27 \mathrm{M}, 1.0$ equiv., approx. $0.4 \mathrm{mmol}$ scale) in dichloromethane under nitrogen and cooled in a dry ice-acetone bath was added dropwise boron tribromide (3.0 equiv.) at $-78{ }^{\circ} \mathrm{C}$ over $2 \mathrm{~min}$. Stirring was continued at $-78{ }^{\circ} \mathrm{C}$ for a further $10 \mathrm{~min}$. The dry ice- acetone bath was then removed and the mixture allowed to warm to $20^{\circ} \mathrm{C}$ over $1 \mathrm{~h}$. Saturated aqueous sodium hydrogen carbonate $(20 \mathrm{~mL})$ was then added and the mixture was stirred at $20{ }^{\circ} \mathrm{C}$ for a further $10 \mathrm{~min} .{ }^{[41]}$ The mixture was extracted with diethyl ether $(3 \times 20 \mathrm{~mL})$ and the combined organic layers were washed with saturated aqueous sodium hydrogen carbonate then with brine. The combined organic layers were dried $\left(\mathrm{MgSO}_{4}\right)$, filtered and the solvent was evaporated. The residue was purified by column chromatography, typically using $10-30 \%$ by volume of ethyl acetate in hexane as the eluent to give the resorcinol derivative (details provided for each compound in Supporting Information).

General procedure B (metalation of a 1,3dimethoxyarene, addition to a ketone and dehydration of the carbinol): To a stirring solution of the 1,3dimethoxy-5-substituted benzene (0.2 M, 1.0 equiv., approx. $1.5 \mathrm{mmol}$ scale) in dry tetrahydrofuran at $0{ }^{\circ} \mathrm{C}$ under nitrogen was added $n$-butyllithium (1.6 M, 1.1 equiv.) dropwise over $5 \mathrm{~min}$. Stirring was continued at $0{ }^{\circ} \mathrm{C}$ for a further $1 \mathrm{~h}$. A solution of the cyclic ketone (1.8 $\mathrm{M}, 1.5$ mol equiv.) in dry tetrahydrofuran was then added dropwise over $10 \mathrm{~min}$. The mixture was stirred for an additional $30 \mathrm{~min}$ at $0{ }^{\circ} \mathrm{C}$, then at $20^{\circ} \mathrm{C}$ for $18 \mathrm{~h}$. Saturated aqueous ammonium chloride $(20 \mathrm{~mL})$ was then added. The mixture was then extracted with diethyl ether $(2 \times 20$ $\mathrm{mL}$ ) and the combined organic layers were washed with water, dried $\left(\mathrm{Na}_{2} \mathrm{SO}_{4}\right)$, filtered and the solvent was evaporated. The residue was purified by column chromatography, typically using $10-25 \%$ by volume of ethyl acetate in hexane as the eluent to give the tertiary alcohol (details provided for each compound in Supporting Information).

General procedure C (reductive elimination of carbinols, and reduction of alkenes to the corresponding aryl cycloalkanes): To a stirring solution of the tertiary alcohol or the alkene $(0.36 \mathrm{M}, 1.0$ equiv.) in dichloromethane at $20{ }^{\circ} \mathrm{C}$ was added trifluoroacetic acid (5.5 equiv.), whereupon the colourless solution immediately turned dark red. Stirring was continued at $20{ }^{\circ} \mathrm{C}$ for $15 \mathrm{~min}$, then triethylsilane (2.5 mol equiv.) was added dropwise over $5 \mathrm{~min}$, and the mixture stirred a further $1.5 \mathrm{~h}$. Saturated aqueous sodium hydrogen 
carbonate $(20 \mathrm{~mL})$ was then added. The organic layer was separated, washed with water $(10 \mathrm{~mL})$, dried $\left(\mathrm{Na}_{2} \mathrm{SO}_{4}\right)$, filtered and the solvent was evaporated. The residue was purified by column chromatography, typically using $0-5 \%$ by volume of ethyl acetate in hexane as the eluent to give the aryl cycloalkane (details provided for each compound in Supporting Information).

\section{General Procedure D (condensation of resorcinol} derivatives with cyclic allylic alcohols): To a stirring solution of the resorcinol derivative $(0.20 \mathrm{M}, 1.0$ equiv., approx. $0.5 \mathrm{mmol}$ scale) and camphorsulfonic acid $(0.10$ mol equiv.) in dichloromethane was added dropwise a solution of the cyclic allylic alcohol $(0.20 \mathrm{M}, 1.5$ equiv.) in dichloromethane via a syringe pump at $20^{\circ} \mathrm{C}$ over $3 \mathrm{~h}$. The solution was stirred for a further $3 \mathrm{~h}$ at $20{ }^{\circ} \mathrm{C}$ then saturated aqueous sodium hydrogen carbonate $(10 \mathrm{~mL})$ was added. The mixture was extracted with dichloromethane $(3 \times 20 \mathrm{~mL})$ and the combined organic layers were washed with water, then with brine. The combined organic layers were dried $\left(\mathrm{Na}_{2} \mathrm{SO}_{4}\right)$, filtered and the solvent was evaporated. The residue was purified by column chromatography (details provided in Supporting Information: usually using $5 \%$ by volume of ethyl acetate in hexane for cannabinoids) to give the cycloalkenyl resorcinol derivative.

\section{Representative general procedure E (Oxidative} dearomatisation of resorcinol derivatives using Frémy's salt): The detailed procedures and quantities given in the Supporting Information for specific reactions should be used, especially the quantity of Frémy's salt. To a stirring solution of the resorcinol derivative $(0.10 \mathrm{mmol})$ in acetone $(5.0 \mathrm{~mL})$ at $20^{\circ} \mathrm{C}$ was added dropwise over 2 min a pre-mixed buffered aqueous solution containing potassium dihydrogen orthophosphate $(0.24 \mathrm{mmol}, 0.060$ $\mathrm{M}, \quad 4.0 \mathrm{~mL}$ ) and Frémy's salt (dipotassium nitrosodisulfonate, $0.268 \mathrm{~g}, 1.0 \mathrm{mmol}$; CAUTION!). Only small quantities of Frémy's salt were used, and under the conditions described did not lead to a rapid exotherm. However, the use of Frémy's salt represents an explosion hazard, and suitable protection during handling and use should be taken. After stirring at $20^{\circ} \mathrm{C}$ until the reaction was complete by TLC (typically 3-4 $\mathrm{h}$ ), the mixture was extracted with diethyl ether $(3 \times 10 \mathrm{~mL})$. The combined organic layers were dried $\left(\mathrm{MgSO}_{4}\right)$, filtered and evaporated. In most cases the hydroxyquinone product was of high purity, as assessed by ${ }^{1} \mathrm{H}$ and ${ }^{13} \mathrm{C} N M R$ spectroscopy and TLC, but could be further purified by column chromatography, typically using $2 \%-10 \%$ by volume of ethyl acetate in hexane.

\section{Topoisomerase I DNA cleavage assay}

Human recombinant topoisomerase I (Affymetrix) was supplied in a storage buffer ( $15 \mathrm{mM}$ sodium phosphate, $\mathrm{pH}$ 7.1, $700 \mathrm{mM} \mathrm{NaCl}, 0.1 \mathrm{mM}$ EDTA, $0.5 \mathrm{mM}$ DTT, 50\% glycerol) at a concentration of 20 units $/ \mu \mathrm{L}$ and was stored at $-20{ }^{\circ} \mathrm{C}$. Inhibitor solutions were prepared by serial dilution of a $10 \mathrm{mM}$ stock solution in DMSO with relaxation buffer $(20 \mathrm{mM}$ Tris- $\mathrm{HCl} \mathrm{pH}$ 7.5, $200 \mathrm{mM} \mathrm{NaCl}, 0.25 \mathrm{mM}$ EDTA, 5\% glycerol). To each Eppendorf tube was added supercoiled plasmid DNA (pBR322, $0.3 \mu \mathrm{g}$ ) followed by different concentrations of HU-331 (0.3 $\mu \mathrm{M}$ to $1 \mathrm{mM})$. Human recombinant topoisomerase I $(2 \mathrm{U})$ was added to each mixture, making the final volume up to $30 \mu \mathrm{L}$. The mixtures were incubated together at $37^{\circ} \mathrm{C}$ for $45 \mathrm{~min}$. The reactions were then terminated by addition of the stopping buffers SDS and proteinase $K$ to a final concentration of $0.25 \%$ and $250 \mu \mathrm{g} / \mathrm{mL}$ respectively. The reaction mixtures were incubated at $50{ }^{\circ} \mathrm{C}$ for $30 \mathrm{~min}$ then analysed by electrophoresis on $1 \%$ agarose gel with $0.5 \mu \mathrm{g} / \mathrm{mL}$ ethidium bromide in a $10 \%$ Tris-borate EDTA buffer. The different forms of DNA were then separated by electrophoresis at $90-140 \mathrm{~V}$ conducted at room temperature for approximately $2 \mathrm{~h}$. Gels were photographed under UV irradiation using a UV transilluminator coupled with a camera.

\section{DNA Intercalation assay}

A literature procedure, reported by Peixoto and coworkers, ${ }^{[51]}$ was used to investigate the intercalation activity of HU-331 compared to ethidium bromide based on the topisomerase I relaxation assay. Inhibitor concentrations were made by serial dilution of stock solutions $(10 \mathrm{mg} / \mathrm{mL}$ for ethidium bromide and $10 \mathrm{mM}$ for HU-331) with topoisomerase I relaxation buffer $(20 \mathrm{mM}$ Tris- $\mathrm{HCl} \mathrm{pH}$ 7.5, $200 \mathrm{mM} \mathrm{NaCl}, 0.25 \mathrm{mM}$ EDTA, 5\% glycerol). To each Eppendorf tube was added supercoiled plasmid DNA (pBR322, $0.3 \mu \mathrm{g}$ ) followed by different concentrations of ethidium bromide $(0.03-3 \mu \mathrm{M})$ and $\mathrm{HU}$ - 
$331(0.03-100 \mu \mathrm{M})$. Human recombinant topoisomerase I $(5 \mathrm{U})$ was added to each mixture, and the final volume made up to $30 \mu \mathrm{L}$ using dilution buffer. The mixtures were incubated together at $37{ }^{\circ} \mathrm{C}$ for $45 \mathrm{~min}$. Reactions were then terminated by addition of the stopping buffers SDS and proteinase $\mathrm{K}$ to a final concentration of $0.25 \%$ and $250 \mu \mathrm{g} / \mathrm{mL}$ respectively. The reaction mixtures were incubated at $50{ }^{\circ} \mathrm{C}$ for $30 \mathrm{~min}$ then analysed by electrophoresis on $1 \%$ agarose gel in a $10 \%$ Tris-borate EDTA buffer. The different forms of DNA were then separated by electrophoresis at $150 \mathrm{~V}$ conducted at room temperature for approximately $2 \mathrm{~h}$. The gels were visualised by staining with ethidium bromide $(0.5 \mu \mathrm{g} / \mathrm{mL})$ for $30 \mathrm{~min}$ then de-staining in water for $15 \mathrm{~min}$. The gels were photographed under UV irradiation using a UV transilluminator coupled with a camera.

\section{Topoisomerase II relaxation assay}

The procedure was similar to the topoisomerase I relaxation assay but with slight modifications. ${ }^{[52]}$ Each inhibitor was tested at one concentration $(80 \mu \mathrm{M})$ by diluting the stock concentrations with topoisomerase II dilution buffer (10 mM sodium phosphate $\mathrm{pH} 7.1,50 \mathrm{mM}$ $\mathrm{NaCl}, 0.2 \mathrm{mM}$ DTT, $0.1 \mathrm{mM}$ EDTA, 10\% glycerol and 0.5 $\mathrm{mg} / \mathrm{mL}$ BSA. To each Eppendorf tube was added human recombinant topoisomerase II $(2 \mathrm{U})$ followed by reaction buffer (100 mM Tris- $\mathrm{HCl}$ (pH 7.9), 500 mM KCl, 500 mM $\mathrm{NaCl}, 50 \mathrm{mM} \mathrm{MgCl} 2,1 \mathrm{mM}$ EDTA, $0.15 \mathrm{mg} / \mathrm{mL}$ BSA and $10 \mathrm{mM}$ ATP) diluted tenfold. To this mixture was added the diluted inhibitor to give a final concentration of $80 \mu \mathrm{M}$. The mixtures were incubated for at room temperature for $10 \mathrm{~min}$ then the supercoiled DNA substrate $(0.3 \mu \mathrm{g})$ was added, making the final volume up to $30 \mu \mathrm{L}$. The mixture was then incubated at $37{ }^{\circ} \mathrm{C}$ for 30 min prior to reaction termination with the stopping buffers SDS and proteinase $\mathrm{K}$ to give a final concentration of $0.25 \%$ and $250 \mu \mathrm{g} / \mathrm{mL}$ respectively. The mixture was then analysed on $1 \%$ agarose gel in a $10 \%$ Tris-borate EDTA buffer. The different forms of DNA were then separated by electrophoresis at $150 \mathrm{~V}$ conducted at room temperature for approximately $2 \mathrm{~h}$. Gels were visualised by staining with ethidium bromide $(0.5 \mu \mathrm{g} / \mathrm{mL})$ for $30 \mathrm{~min}$ then destaining in water for $15 \mathrm{~min}$. The gels were photographed under UV irradiation using a UV transilluminator coupled with a camera. For quantitation, the integrated pixel intensities of the ethidium bromide fluorescence were determined using ImageJ software. Background fluorescence (mainly from open circular 'nicked' DNA) was subtracted from all fluorescence values to give normalised intensities, the percentage inhibition being given by $100-$ $100 \times$ (normalised intensity for relaxed DNA formed).

\section{Cell proliferation XTT assay}

A procedure for an MTT assay was used with the following adaptations. ${ }^{[53]}$ DU-145 cells were suspended in RPMI 1640 medium, supplemented with fetal calf serum $(40 \mathrm{~mL})$ and L-glutamine $(5 \mathrm{~mL})$ at $37^{\circ} \mathrm{C}$ in a humidified atmosphere of $5 \% \mathrm{CO}_{2}$ and $95 \%$ air. Aliquots $(200 \mu \mathrm{L})$ of suspensions of cancer cells were dispensed into wells of 96-well tissue culture plates at densities of 4000 cells/well. After incubation for $24 \mathrm{~h}$ various concentrations of the 2hydroxy-1,4-benzoquinone derivative were added and cell viability determined after $72 \mathrm{~h}$ using 2,3-bis-(2-methoxy-4nitro-5-sulfophenyl)-2H-tetrazolium-5-carboxanilide (XTT) in the presence of phenazine methosulfate (PMS). Absorbance was measured against a background control as a blank (0.5\% DMSO in growth medium) using a scanning multiwell spectrophotometer (Wallac Victor 1420 multilabel counter) at $450 \mathrm{~nm}$. IC $\mathrm{C}_{50}$ values for various compounds were then calculated using OriginPro 9 by plotting the Log of the concentrations against the mean percentage inhibition, and using a non-linear curve fit algorithm.

\section{Cell Viability Assay}

Cell lines were purchased from American Type Culture Collection (Manassas, VA). Cells of the DU-145 prostate cancer cell line were grown in EMEM medium, whereas those from Raji human lymphoma and Jurkat human acute T cell leukaemia cell line were grown in RPMI-1640 medium. All culture media were supplemented with $10 \%$ fetal bovine serum, penicillin $(100 \mu \mathrm{g} / \mathrm{mL})$ and treptomycin $(100 \mu \mathrm{g} / \mathrm{mL})$. Cultures were maintained at $37{ }^{\circ} \mathrm{C}$ in a humidified atmosphere of $5 \% \mathrm{CO}_{2}$ and $95 \%$ air.

Test compounds and the reference compound staurosporine (Sigma-Aldrich) were prepared in DMSO as $10 \mathrm{mM}$ stock solutions which then were diluted with 10 dose and three-fold dilutions in a source plate. A solution of each test compound $(0.25 \mathrm{~mL})$ or of staurosporine $(0.025 \mathrm{~mL})$ was delivered from the source plate to each 
well of the 384-well cell culture plates by Echo 550 . Culture medium $(25 \mu \mathrm{L})$ containing one thousand cells from the DU-145 prostate cancer cell line, or the Raji human lymphoma cell line, or the Jurkat human acute $T$ cell leukaemia cell line was added to the wells of the cell culture plates. The cells were incubated with the compounds at $37{ }^{\circ} \mathrm{C}$ for $72 \mathrm{~h}$ under an atmosphere of $5 \%$ $\mathrm{CO}_{2}$ and $95 \%$ air. To each well was added Cell Titer Glo 2.0 reagent $(25 \mu \mathrm{L})$ (Promega, Madison, $\mathrm{WI})$, then the contents were mixed on an orbital shaker for 2 min prior to incubation at room temperature for $10 \mathrm{~min}$ to stabilise the luminescent signal. Luminescence was recorded by an Envision 2104 Multilabel Reader (PerkinElmer, Santa Clara, CA). The number of viable cells in culture was determined based on quantitation of the ATP present in each culture well. $I C_{50}$ curves were plotted and $I C_{50}$ values were calculated using the GraphPad Prism 4 program based on a sigmoidal dose-response equation.

\section{Acknowledgments}

Financial support from the Engineering and Physical Sciences Research Council for a PhD studentship to T. D. W. is gratefully acknowledged. Prof. John A. Hartley (UCL Cancer Institute) is thanked for helpful discussions, and $\mathrm{Dr}$ Konstantinos Kiakos and Dr. Luke Pett are thanked for assistance with gel electrophoresis studies.

\section{Conflict of interest statement}

The authors declare no conflict of interests.

Keywords: anti-cancer agents . cannabidiol . Frémy's salt . HU-331. monocyclic quinones . structure-activity relationships .

${ }^{*}$ Corresponding author: e-mail: c.m.marson@ucl.ac.uk FAX: +44(0)20 76797463 .

\section{References}

[1] P. A. Henriksen, Heart 2018, 104, 971.

[2] S. N. Sunassee, M.T. Davies-Coleman, Nat. Prod. Rep. 2012, 29 , 513-535

[3] S M. Gordaliza, Marine Drugs 2010, 8, 2849-2870.

[4] C. A. Asche, Mini-Rev. Med. Chem. 2005, 5, 449-467.

[5] V. McGowan, R. Chung, A. Maulik, I. Piotrowska, J. M. Walker, D. M. Yellon, Cardiovasc. Drugs Ther. 2007, 31, 63-75.

[6] M. M. Paz, A. Das, Y. Palom, Q.-Y He, M. Tomasz, J. Med. Chem. 2001, 44, 2834-2842.

[7] P. Morales, D. Vara, M. Goméz-Cañas, M. C. Zúñiga, C. Olea-Azar, P. Goya, J. Fernández-Ruiz, I. Díaz-Laviada, N. Jagerovic, Eur. J. Med. Chem. 2013, 70, 111-119.

[8] F. Arcamone, G. Cassinelli, Curr. Med. Chem. 1998, 5, 391-419.
[9] G. Barone, C. F. Guerra, N. Gambino, A. Silvestri, A. Lauria, A. M Almerico, F. M. Bickelhaupt, J. Biomol. Struct. Dyn. 2008, 26, 115130.

[10] C. A. Frederick, L. D. Williams, G. Ughetto, G. A. Van der Marel, J. H. Van Boom, A. Rich and A. H. J. Wang, Biochemistry 1990, 29 2538-2549.

[11] J. L. Nitiss, Nat. Rev. Cancer 2009, 9, 338-350.

[12] C. H. Takimoto, E. Calvo, 'Principles of Oncologic Pharmacotherapy' in R. Padzur, L. D. Wagman, K. A. Camphausen, W. J. Hoskins (eds.) Cancer Management: a Multidisciplinary Approach 2008, $11^{\text {th }}$ ed.

[13] B. Pang, X. Qiao, L. Janssen, A. Velds, T. Groothuis, R. Kerkhoven, M. Nieuwland, H. Ovaa, S. Rottenberg, O. van Tellingen, J. Janssen, P. Huijgens, W. Zwart, J. Neefjes, Nat. Commun. 2013, 4, 1908.

[14] C. C. Yu, P. J. Wu, J. L. Hsu, Y. F. Ho, L. C. Hsu, Y. J. Chang, H. S. Chang, I. S. Chen, J. H. Guh, Prostate 2013, 73, 133-145.

[15] U. Mahmood, V. K. Kaul, L. Jirovetz, Phytochemistry 2002, 61, 923926.

[16] A. A. Gunatilaka, J. M. Berger, R. Evans, J. S. Miller, J. H. Wisse, K. M. Neddermann, I. Bursuker, D. G. Kingston, J. Nat. Prod. 2001, 64, 2-5.

[17] R. Mechoulam, N. M. Kogan, R. Rabinowitz, M. Schlesinger, WO/2005/067917, 2005, July 28.

[18] M. Chitra, E. Sukumar, V. Suja, C. S. Devi, Chemotherapy 1994, 40, 109-113.

[19] N. M. Kogan, M. Schlesinger, M. Peters, G. Marincheva, R. Beeri, R. Mechoulam, J. Pharmacol. Exp. Ther. 2007, 322, 646-653.

[20] N. M. Kogan, M. Schlesinger, E. Priel, R. Rabinowitz, E. Berenstein, M. Chevion, R. Mechoulam, Mol. Cancer Ther. 2007, 6, 173-183.

[21] N. M. Kogan, R. Rabinowitz, P. Levi, D. Gibson, P. Sandor, M Schlesinger, R. Mechoulam, J. Med. Chem. 2004, 47, 3800-3806.

[22] C. Petronzi, M. Festa, A. Peduto, M. Castellano, J. Marinello, A Massa, A. Capasso, G. Capranico, A. La Gatta, M. De Rosa, M Caraglia, R. Filosa, J. Exp. Clin. Cancer Res. 2013, 32, 24.

[23] N. Usami, I. Yamamoto, K. Watanabe, Life Sci. 2008, 83, 717-724.

[24] K. M. Regal, S. L. Mercer, J. E. Deweese, Chem. Res. Toxicol. 2014, 27, 2044-2051.

[25] M. Guzmán, Nat. Rev. Cancer 2003, 3, 745-755.

[26] I. Díaz-Laviada, Nat. Rev. Urol. 2011, 8, 553-561.

[27] C. Grimaldi, A. Capasso, Curr. Med. Chem. 2011, 18, 1571-1583.

[28] S. D. McAllister, R. T. Christian, M. P. Horowitz, A. García, P.-Y Desprez, Mol. Cance 
r Ther. 2007, 6, 2921-2927.

[29] A. Preet, R. K. Ganju, J. E. Groopman, Oncogene 2008, 27, 339346.

[30] J. T. Wilson, C. A. Fief, K. D. Jackson, S. L. Mercer, J. E. Deweese, Chem. Res. Toxicol. 2018, 31, 137-144.

[31] N. Kogan, Mini-Rev. Med. Chem. 2005, 5, 941-952.

[32] N. M. Kogan, C. Blázquez, L. Alvarez, R. Gallily R, M. Schlesinger, M. Guzmán, R. Mechoulam, Mol. Pharmacol. 2006, 70, 51-59.

[33] E. Frémy, Ann. Chim. Phys. 1845, 5, 408-488.

[34] T. A. Engler, R. lyengar, J. Org. Chem. 1998, 63, 1929-1934.

[35] V. Pace, L. Castoldi, P. Hoyos, J. V. Sinisterra, M. Pregnolato, J. M. Sánchez-Montero, Tetrahedron 2011, 67, 2670-2675.

[36] S.-H. Baek, M. Srebnik, R. Mechoulam, Tetrahedron Lett. 1985, 26 , 1083-1086.

[37] S. M. Wilkinson, J. Price, M. Kassiou, Tetrahedron Lett. 2013, 54, 52-54.

[38] F. E. Souza, J. E. Field, M. Pan, N. J. Ramjit, T. Tharmanathan, T. Jende-Tindall, US Patent No. 074,252, 2006, April 6.

[39] A. Makryannis, S. P. Nikas, S. O. Alapafuja, V. G. Shukla, US Patent No. 306,016, 2009, December 10.

[40] M. S. Malamas, T. Q. Dinh, US Patent No. 207,927, 2003, November 6.

[41] P. J. Crocker, B. Saha, W. J. Ryan, J. L. Wiley, B. R. Martin, R. A. Ross, R. G. Pertwee, R. K. Razdan, Tetrahedron 1999, 55, 1390713926.

[42] S.-H. Baek, Bull. Korean Chem. Soc. 1988, 9, 71-77.

[43] D. A. Evans, D. M. Barnes, J. S. Johnson, T. Leckta, P. von Matt, S. J. Miller, J. A. Murry, R. D. Norcross, E. A. Shaughnessy and K. R. Kampos, J. Am. Chem. Soc. 1999, 121, 7582-7594.

[44] J. A. Teske, A. Deiters, Org. Lett. 2008, 10, 2195-2198.

[45] S. P. Acharya, H. C. Brown, J. Am. Chem. Soc. 1967, 89, 19251932.

[46] B. B. Hasinoff, T. I. Kuschak, J. C. Yalowich, A. M. Creighton, Biochem. Pharmacol. 1995, 50, 953-958.

[47] M. Peters, N. M. Kogan, Expert Opin. Investig. Drugs 2007, 16, 1405-1413.

[48] R. P. Bender, A.-J. L. Ham, N. Osheroff, Biochemistry 2007, 46, 2856-2864.

[49] H.-Y. Wu, T.-R. Jan, Toxicol. Lett. 2010, 195, 68-74

[50] D. lacopetta, C. Rosano, F. Puoci, O. I. Parisi, C. Saturnino, A. Caruso, P, Longo, J. Ceramella, A. Malzert-Fréon, P. Dallemagne, S. Rault and M. S. Sinicropi, Eur. J. Pharm Sci. 2017, 96, 263-272.

[51] P. Peixoto, C. Bailly, M.-H. David-Cordonnier, Methods Mol. Biol. 2010, 613, 235-256.

[52] X. Pan, J. M. Hartley, J. A. Hartley, K. N. White, Z. Wang, S. W. A. Bligh. Phytomedicine 2012, 19, 618-625.

[53] T. Mosmann, J. Immunol. Methods 1983, 65, 55-63. 


\section{Entry for the Table of Contents}

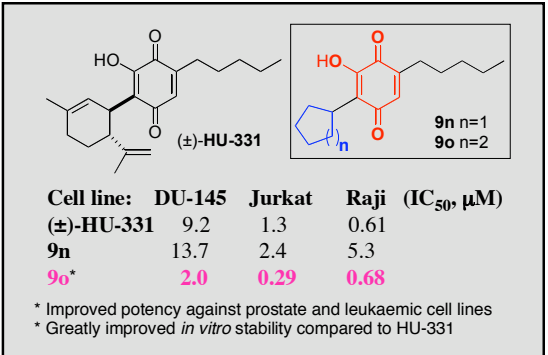

Many potent anti-cancer and antibiotic agents contain a fused 1,4-benzoquinone ring, but also show dose-limiting cardiotoxicity. Noting the lack of cardiotoxicity of the monocyclic quinone HU-331, new monocyclic quinones were synthesised to determine their anti-cancer properties and identify a provisional pharmacophore. We describe a crystalline monocyclic quinone that like HU-331 is also a topoisomerase Il $\alpha$ inhibitor but showed greater potency against DU-145 and Jurkat cell lines, as well as having much greater stability in solution than HU-331. 